\title{
'THEY WON'T LET US COME, THEY WON'T LET US STAY, THEY WON'T LET US LEAVE'. LIMINALITY IN THE AEGEAN BORDERSCAPE: THE CASE OF IRREGULAR MIGRANTS, VOLUNTEERS AND LOCALS ON LESVOS
}

Ioanna Tsoni Department of Global Political Studies, Malmö University

\section{Abstract}

This paper draws on ethnographic observations along the south-eastern Mediterranean informal migration route through the Aegean Sea. I focus on the Greek border island of Lesvos as the central stage where the European crisis of asylum has been recently unfolding. In the absence of coherent national and European asylum policies, newly arrived migrants, refugees, and receiving communities (comprised mainly of local residents and volunteers from mainland Greece and Europe) are left to cope with and against each other, leading to multiple personal and collective passages. In this interstitial transit space, subjectivities are made and remade through their participation and resistance to the ongoing production of EU borders. I suggest that liminality provides a useful lens through which to understand the perplexing 'time-spaces' and interactions between multiple actors involved in the teetering asylum system on the margins of Europe. I argue that, through various actors' experiences on
Lesvos as a complex social site, liminality emerges as a form of sustained social marginality and exclusion that extends beyond Lesvos itself. The protracted and broadened crisis context in which asylum-seekers and receiving communities of locals and volunteers on Lesvos find themselves provides a salient example of the gradual socio-spatial and temporal 'stretching' of liminality from a transitional phase towards a condition of permanent and portable liminality experienced at both the individual and the collective level, and both at and away from borders.

Keywords: Lesvos, borderscape, asylum-seekers, liminality, rite of passage, volunteers

'Ellos no dejan que lleguemos, no dejan que nos quedemos, no dejan que nos vayamos.' Liminalidad en el paisaje fronterizo Egeo: el caso de los migrantes irregulares, voluntarios y gente local de Lesbos 


\section{Resumen}

Este artículo se basa en observaciones etnográficas a lo largo de la ruta de migración informal del sudeste mediterráneo a través del mar Egeo. Me centro en la isla fronteriza griega de Lesbos como escenario central en el que la crisis europea de asilo se ha estado recientemente desarrollando. En ausencia de políticas coherentes nacionales y europeas de asilo, migrantes recién llegados, los refugiados y las comunidades receptoras (compuestas principalmente por los residentes locales y voluntarios de la Grecia continental y Europa) se quedan con el cargo de enfrentarse en conjunto y en contra de los demás, dando lugar a múltiples pasajes personales y colectivos. En este espacio intersticial de tránsito, subjetividades se hacen y rehacen a través de su participación y de la resistencia a la producción continua de las fronteras de la UE. Sugiero que liminalidad proporciona un lente útil para comprender los desconcertantes "espacio-tiempos" y las interacciones entre múltiples actores involucrados en el sistema de asilo que tambalea en los márgenes de Europa. Argumento que, a través de las experiencias de diferentes actores de Lesbos como un sitio social complejo, liminalidad surge como una forma de marginalidad social sostenido y exclusión que se extiende más allá de Lesbos en sí. El contexto de crisis prolongada y ampliada en el que se encuentran los solicitantes de asilo y las comunidades recipientes de residentes y voluntarios en Lesbos proporciona un ejemplo destacado del progresivo 'estiramiento' socio-espacial y temporal de liminalidad de una fase de transición hacia una condición de permanente y portátil liminalidad experimentado tanto en el nivel individual como colectivo, y tanto cerca como lejos de las fronteras.

Palabras clave: Lesbos, paisaje fronterizo, solicitantes de asilio, liminalidad, rito de paso, los voluntarios

\section{Introduction}

As the morning ferry from Piraeus approaches, Lesvos emerges receptive and tranquil from the crystalline Aegean waters. Through the thin mist the island hangs suspended on the edge of a narrow sea splintered by the gash of a border drawn some 90 years ago by the Treaty of Lausanne in 1923, separating Lesvos from its geological roots on Anatolia (now Turkey). Since the early 2000s, the island has been transformed from an idyllic tourist destination into a leading gateway of informal migration into Europe. With a handful of other border islands (including Samos, Chios, Kos and Leros), Lesvos lies on the historically established yet recently hyperactivated 'arc of arrival' that stretches across the maritime border between Greece and Turkey. Since 2008 the number of informal arrivals has been steadily increasing, reaching an unprecedented peak during the summer months of 2015. This pattern continued unabated throughout the fall, and then decreased slightly during the first months of 2016. After the EU-Turkey Repatriation Agreement was signed on 8 March 2016, migration was brought to a sudden halt. However, as one migration epoch draws to an end another re-opens, as recent political developments divert migration flows once more to far more perilous crossings, from Libya towards the Italian shores.

Through the following research questions, I intend to problematize the concurrence or divergence of experiences and practises of various actors who inhabit however temporarily - this border landscape. Is Lesvos an idyllic tourist destination, home to a vibrant, laidback, hospitable community, as depicted in tourism advertisements? Is it an island of refuge for the persecuted? Is it yet another sovereign border? Is it a frontier of pioneering self-realization through philanthropic humanitarianism, as some volunteers suggest, or is it a site of ritualistic, streamlined irregular passage, as the migrants might lead us to believe? Or is this border at the edges of Europe a line looping itself into a noose-like, ever-diminishing, selectively permeable, carceral space of indefinite legal and socio-spatial liminality?

This article grew out of ethnographic fieldnotes, participant observation, and personal experience on Lesvos from 2012 to the present. During this time I was actively involved in local responses to refugees on the island in different capacities. Most recently, I spent December 2015 volunteering with the front line of boat rescue and reception with a lifeguard association stationed on the beach of Molyvos Lighthouse on the northern shore of Lesvos. Through these visits I created the following original data sources which I draw upon for this article: in-depth discussions and informal 
interviews, personal narratives and testimonies, participant observation, recollections from research diaries paired with online ethnography, mobile methods and ethnographic film-making.

I use these data to create a composite sketch of the changing seasons of migration on the island. As part of my analytic approach in this article, I weave an evocative text that attempts to mirror the complex borderscape as I and others experience it. I purposefuly employ autoethnographic description as a heuristic device in order to situate readers within specific sensory and affective landscapes, which feel almost unshakeable for all those who went through them. These are 'affective environments in which one cannot be at ease... [which] nevertheless stick with the observer, as much as they haunt those who live in them every day' (Stoetzer 2014).

This paper approaches the 2015 refugee exodus towards Europe as a ritual passage through Lesvos, and provides an ethnographic analysis of liminality as a protracted socio-spatial and temporal condition in a borderland locality emerging as a Foucauldian 'crisis heterotopia' (Foucault and Miskowiec 1986). First, I discuss the concept of liminality within the field of human geography with regard to mobility and migration studies. I then dive into the visceral aspects of island life during the last few months by providing a self-reflective look at the encounters and perspectives of different actors whose trajectories crossed and reached an impasse on Lesvos. As old identities come apart and social norms and rituals loosen and dissolve, new meanings and selfhoods arise in liminal spaces. Whatever life on the island once used to be, it has now been indefinitely suspended. This holds true not only for the irregular border-crossers but for the receiving communities as well - both locals and volunteers - as everyone is captured in the legal, socio-spatial and affective limbo of routinized liminality.

\section{Liminality in human geography and migration studies}

The concept of liminality used in this article derives from social anthropology and signifies the 'betwixt and between' state experienced by persons undergoing a ritualistic identity transition. According to this model, transition occurs in three successive stages: separation, liminality, and aggregation. Space, community, temporality and mobility, concepts central to human geography, can be seen as embedded within rites of passage. They are integral to the liminal middle stage, too: it is from within an emplaced community that, upon the occurrence of a 'triggering event', the liminal subjects must depart, distance themselves for an extended duration of time, and eventually return to in order to reap the upgrade of their social status within their former community as a reward for their trials.

According to van Gennep's conceptualization of 'rites of passage' (1960), after the eruption of a 'triggering event' a person sheds one identity state and embarks on a transformation that follows three successive, linear stages. These stages have fixed durations and follow specific rules of conduct, taking place in particular sites usually hidden away from common sight. During the pre-liminal phase of separation/segregation, the subject detaches from his or her community and rejects previous symbols and codes. During the liminal stage, the subject enters an ambiguous phase of transition/suspension of identification. In this phase few, if any, of the attributes of the 'before and after' stages can be discerned and social rules are suspended, as subjects belong to neither the 'old' nor the 'new' subject position. The consummation of the passage comes during the third phase of reintegration/aggregation (post-liminal stage) where, after having successfully completed the trials of the middle stage, liminal subjects are now invested with a new identity and an elevated social position which allow them to re-enter society.

Victor Turner (1967), extending van Gennep's work, conceptualized the liminal subject as an 'interstructural' being occupying a 'betwixt and between' position. During this time, persons undergoing this ceremonial transition are required to be socially and physically invisible, remaining subdued and ambiguous in a shapeless, malleable form that evades external definition. While in this phase, outcasts are considered unclean. They are psychically sullied and physically polluting to all those who have not been 
immunized against them. They become explicitly tethered to possible death, ceremonially prescribed to them as structural and physical extinction. They are divested of all their rights. Stripped of possessions and personhood, they owe complete obedience to the elders and the ceremonial masters who have the sole power to decide their fate.

In Turner's conceptualization, dramaturgy and performance are at work in the ritual passage. Social dramas are viewed as 'units of aharmonic or disharmonic social processes, arising in conflict situations' (1979: 63) and they 'demand a stage, actors, a heightened atmosphere, spectators, the smell .... and roar of the crowd', calling forth the full spectrum of sensuality and affect (1979: 94). Dramas are sequenced into acts or 'moves'. Actors and audiences are moved between the different stages through dialogue and performance, and they get moved emotionally and mobilized physically so the transition may conclude. Turner adds the notion of 'ritual reversal' in the performance of a social drama, where 'turnabouts of normal social status' would occur (i.e. the rich would impersonate the poor and vice versa). He also lays out the idea of the frames enclosing such dramatized events within some types of border - physical or symbolic - usually by the social and political hierarchy of a given community. Those at the top of the hierarchies have the full capacity to script, punctuate and signify the content and the sequence of the ritual's episodes. Carved off from 'everyday' space, the incidents unfolding within those frames are offered up as a spectacle to non-participants. The social outcome of such performances is expected to relate to the unity and continuity of the nation, its identity and territory.

The concept of liminality as an analytical tool has much to offer refugee and migration studies. Indeed, 'legal liminality' (Menjívar 2006) has been explored as the superimposition of 'liminality as a spatial phenomenon' with 'liminality as a legal status'. In this sense, the production of spaces of liminality, such as borders and detention centers, corresponds to the production of irregular migrants as liminal legal subjects. Menjívar (2006: 1032) uses this concept of 'liminal legality' as a way to gain leverage into the 'mighty impact of law' on the everyday lives of immigrants both at and beyond borders. Recently, however, through the intensification of the processes of criminalization of solidarity towards migrants and refugees, not only are newcomers faced with impeding liminal legality but anyone else showing support is too.

With a few notable exceptions, however, the concept is underutilized in human geography. It should gain traction, especially with regard to the examination of the refugee passage and the emergent assemblages of actors located in differential and persistently ambiguous structural positions within the changing circumstances of the ongoing European crisis of asylum and its political project of borders. The relational examination of the interlocking experiences and voices of people coming together within the transitive refugee space-time of Lesvos reveals that these embodied, affective and visceral aspects of living along the very edges of everything that Europe and the European Union have come to symbolically stand for are conceptually exceeding a condition of mere socio-spatial marginality. The transitiveness and ambiguity characterizing a liminal period affect not only persons undergoing it, but also the spaces within which the passage occurs. These qualities make liminality an essentially, although underutilized, spatial concept. In this study it became a conceptual device facilitating the examination of protracted socio-legal ambiguity and abstruseness experienced by everyone encompassed within the south-eastern European borderscape around Lesvos.

\section{Passage as an impasse}

The year 2015 will remain forever etched in the local as well as the international collective memory as the year of the 'great refugee exodus' towards Europe. Around 500,000 arrivals on Lesvos alone were recorded in 2015 out of a total of 860,000 registered arrivals throughout the Greek islands (UNHCR 2015, 2016). As a result, Lesvos became the indisputable 'gateway island' for irregular migrants entering Europe.

Refugee statistics provide a broad measurement of the magnitude of migration, but do not illuminate the significant social interactions that take place at the scale of the everyday. Migrants and refugees had been 
landing for years on the northern and south-eastern coastlines of Lesvos, leading to the normalization of small groups of tired, bewildered people growing to larger columns and caravans. In the past, after landing they would hide their lifejackets and destroy their rubber dinghies so that they would be deemed to be castaways in case of interception, as they were instructed to do by the irregular travel facilitators on the Turkish side. They would then change into dry clothes and set out on foot from the disembarkation zone to the island's capital, Mytilene, to register their asylum claim. Only there could they obtain the coveted 'fyge' - the police registration and release paper allowing them to buy a ticket and board the ferries to mainland Greece and continue towards Northern Europe.

Upon arrival, without official documents or guidance from any authority (as neither the police nor the coastguard had a clearly dictated legal responsibility towards them), migrants and refugees had to stumble along for several days, in a long single file by the narrow roadside of the island's winding rural highways. They carried their bags, dragged their exhausted children, their elderly and their sick up the steep hills and across the long sweeps of rugged, desert-like plains. Under the scorching sun or pouring rain they stumbled along: human refuse on a 'death march', banned from hiring a taxi or getting on public transport as they set out to cover the ground from the northern shores of Lesvos to Mytilene - a distance of up to $100 \mathrm{~km}$ from their arrival points. These human caravans had become a common sight on Lesvos.

The phrase 'They won't let us come, they won't let us stay, they won't let us go' emerged as a cry of exasperation since the first surge in irregular arrivals on Lesvos in 2008. It arose from the collective experiences and narratives of refugees on the island who found themselves caught in an impossible situation. If they did not get illegally pushed back to Turkey while crossing, they were received with indifference or hostility by the local authorities and simultaneously prevented from leaving the island or Greece due to the legal and political restrictions imposed on their mobility. The phrase soon became a slogan shared by immigrants and anyone expressing solidarity with them. It was spraypainted on walls, shouted out during demonstrations, and used as an argument in public debates on these issues.

The first moments after a boat landed safely ashore were 'affectively saturated' for everyone involved - hectic and emotional. A ritual passage through the fearsome wilderness and its unpredictable natural forces - the sea and the dark night - appeared completed. Little was known then of the shifting political and legal landscape awaiting refugees ahead. Save for the deep relief and renewed hope expressed by the newly arrived, it was a yearning for the next stage to begin that set the tone of all encounters: that of the eventual social re-entry and its tranquillity and peace; of having, eventually, transitioned. Similar to the makeshift pre- and post-departure ceremonies (such as divination prayers to bless their boat, pouring oil to calm the sea or holding holy books open over the waves to 'take demons out of the water'), small personal rituals of arrival happen immediately after the first steps on the 'other' side: receiving hot tea prepared 'the arab way' by volunteers, sharing food, taking pictures, asking for the direction of Mecca so prayers can be said, kissing the ground, playing musical instruments and singing. A rare video was recorded of such a ritualistic performance to celebrate the perceived conclusion of the irregular journey and the conclusion of the liminal period after the landing of a refugee boat somewhere on Lesvos in early 2016. Accentuating the 'subjunctivity of ritual' (Turner 1967), a young man bursts into a spontaneous mourning song, here below translated from the Arabic, describing the ritual passage of crossing the sea border, invoking its human, material, affective and phantasmatic aspects, and imploring the sea to now let them have peace and move forward (Aldeen 2016):

Oh sea, give us love

Look what has happened to us

Do not send your waves against us

We are Syrians, I swear to you,

Our story is sad 
Oh you will not believe it, but our tears can drown even you

This is how much we have cried

We have accepted all the people with kindness and love

But when we fell down they all betrayed us

No-one mourned for us

Oh today the whole world has abandoned us

Oh sea, stop the waves

There were children in the boats who are our memories

Our lives are in these boats

I swear to you, our tears could cover all the seas of the world

Our children have lost their childhood upon your waves

The boats carry the dreams of childhood that seek a harbour

And your waves have killed our children

Oh sea, let your waves have mercy on us,

To care for us like a mother would

Oh for us Syrians fate is heavy

Let us only have peace, this is the only thing that we want

And now, we will keep moving forward

So that we may find some kind of tranquillity and peace.
At first the (is)land is hailed as a safe place in which to take refuge from the perilous, unforgiving sea but then the need to move forward spatially, temporally and affectively, exiting this ambiguous condition, is emphatically expressed. As the song breaks the dawn, the shores bridged by the nightly boat-crossing, together with the people scurrying around before the UNHCR bus to the registration camp leaves, the deflated grey plastic boat, the small hill of lifejackets, the Greek coastguard boat in the near distance, the lost childhood dreams, and the ruins of Syria all stand suspended in space and time: in between the old and the new, the East and the West, the past and the present, and uncertainty and hope.

Forward movement into the next 'act' of the passage as social drama will occur at different speeds from that point on. Newcomers, however, are inevitably marked by Lesvos already: by their irregular arrival on its shores, the people awaiting for them there, the documents they were furnished with, the official stamps, their fingerprints, their stories. All these are to be tied with the islands name: to be memorized together with their arrival date - like a new birthday - as every immigrant I had ever discussed this with professed. Lesvos as an entry point into Europe marks the newcomers' experiences and feelings, introduces them to yet another liminal phase, fixing it on their now-'embordered' bodies.

The exponential increase of volunteers and humanitarian organizations arriving to offer help provides yet another account of this crossing's rapid intensification. Prior to the 2015 swell in arrivals, irregular border-crossers were only occasionally met by small local initiatives and a handful of supportive Lesvos citizens who tried to facilitate their landings and reception by offering clothes, food, general advice and an occasional ride in their private vehicles, risking arrest and human-smuggling charges in so doing. During the second phase of the so-called 'refugee crisis', between September and November 2015, up to 7,000 refugees arrived in Lesvos daily. Their first reception became a free-for-all feast, and the few pre-existing local voluntary organizations were trampled over by up to 100 national and international organizations, agencies and solidarity collectives, as well as thousands 
of independent international volunteers soon rushing in. Along with them, throngs of journalists, photographers, activists, researchers, statutory personnel, entrepreneurs, profiteers, curious tourist-volunteers, scavengers and anyone-in-between turned up. All the while, any official political or administrative response from the Greek or the European authorities remained glaringly inefficient, if not entirely absent. The burden of rescue, reception and assistance fell, therefore, almost exclusively on the voluntary and statutory organizations' shoulders, despite the improvisational nature of their response. As volunteer involvement broadened and intensified, a 'volunteering culture' gradually emerged and climaxed both offline and on, assuming different patterns, symbolic hierarchies and identity markers according to 'job' specificities, the tasks at hand (search and rescue, shorewatch, clothes/ food distribution, medical/legal assistance etc.), length of stay, and the myriad motivations and organizational cultures guiding each individual and NGO.

Volunteerism on the island is a paradigmatic example of liminal work as it takes place within sharply shifting circumstances, as people create and recreate loose networks within and between organizations, adapting to the conditions at hand. When the small window of opportunity of the 'Balkan route', which allowed migrants to easily travel to Northern Europe, was closed after the sealing of the Greek borders with the Former Yugoslav Republic of Macedonia, both mainland Greece and the islands came under the tremendous pressure of unabated arrivals. Makeshift camps mushroomed all over the country. Since 20 March 2016, when the EU-Turkey Repatriation Agreement came into effect, the liminal loop in which people are caught gets ever smaller, harsher, and more acute. The support community created on Lesvos was almost entirely dismantled but for a few core structures at specific locations that persist.

The throngs of volunteers have either scattered around Greece following around the leftover migrants on Greek territory, or moved against the incoming current - beyond the Greek borders into Turkey or further away to Lebanon and Jordan. Others just returned home, where they often rehash memories from Lesvos online or by meeting up with other vol- unteers. The majority of the volunteers on Lesvos had no prior relation or involvement (personal, educational or professional) with refugee issues and they would usually come at times signifying a critical juncture in their own lives - graduation, retiring and going on a pension, and personal crises such as divorce, leaving their jobs etc. Island memories, especially those revolving around certain high-profile activities such as the nightshifts of coastline boat reception, are hard to leave behind and therefore often retold. The persistent and detailed recollection of those incidents sometimes appears as a fixation overrun by feelings of 'being stuck' (kollimenos), as Papataxiarchis (2016) has also ethnographically observed. A characteristic example is offered in the following status update from a volunteer's Facebook page who bumped into another volunteer at a pro-refugee demonstration in Stockholm.

Met this guy at the refugee demonstration in Stockholm today, and I was instantly back in Lesvos. A cold, wet and windy night in October, taking in boats around midnight in the area west of Light House camp in Skala Sikamineas. Five boats landing simultaneously on a $1 \mathrm{~km}$ stretch. In the pitch black, where all the senses registered were the ice-cold rain, the wind distorting the sound of frightened refugees, and the rough seas with waves rumbling over the rocky shore. In his dark clothes walking out of the dark, surrounded by disoriented refugees and stressed out volunteers with headlamps, smiling, calm as ever. Together with dedicated volunteers we made sure all the refugees got dry, a bite to eat and a safe place to sleep that night. You never truly leave Lesvos (Kristoffer, 25, Swedish volunteer).

Volunteers 'roaming' the Greek countryside looking for new formal or informal refugee settlements and camps for the thousands of stranded refugees are portrayed by the media as questionable personalities with dubious motives. Representations of volunteers oscillate between narratives of unadulterated heroism by some and dangerous opportunism or obsession by others - and by the volunteers themselves - each one 
making their own definition of who they are, what they do, and why:

Volunteer? I don't like this word because it suggests that something is for free, but nothing comes for free in this life. I prefer the word 'activist'. Many disagree, but I don't care. Activist. From the word 'act'. That means I'm taking action, I'm doing something, I'm not sitting idle. Who are we? Don't we have jobs? Homes? Families? Why do we leave our children and run in the fields? We are just simple people next door. Unemployed, badly paid clerks, people with diplomas who had to close their practices, students who sacrifice their little pocket money. But you know - during the nights of Moria, the nights of Eidomeni, we didn't exchange resumés, we overcame our fears, we exchanged love in a way that most of us were never taught how to. I can't explain it all. It's something personal. We lost a lot but won just as much. Then it was difficult to go back to our previous life. We felt as if we were in the Matrix - in a parallel artificial reality. Nothing was the same ever again. Not even food tasted the same. The only real burning wish was this: When are we going to return to the field? Field rats. We do not need NGOs. We don't need yellow fluorescent vests. We are not afraid of being arrested or slandered by the media. There are no borders for us. There are no passports. Field rats. That's who we are (Simon, 36, Greek volunteer).

Any reference to the 'refugee crisis' currently faced by Greece is but another facet of the ongoing European crisis of its policies and institutions. These are expressed through the acute shortcomings of the EU asylum system, just as the localized aspects of the 'refugee crisis' are coupled with the financial crisis straining the country since 2008 . The convulsions of compounded crises affected the lives of Greek people, especially those living in remote border areas whose seasonal sector economies face declining growth rates and are met with limited national institutional capacity to alleviate the negative effects of those processes on their most vulnerable populations. On an island of 85,300 inhabitants, many of whom are descendants of Anatolian refugees forced to flee the now-Turkish coastal towns in 1922, a quarter of its population $(23,000)$ had been registered in 2015 as beneficiaries of various municipal social aid programs, such as soup kitchens, social solidarity clinics and food banks (Maravas 2015). The persistent financial crisis has affected local islanders who, like the rest of the increasingly impoverished Greek people, are morally castigated for the country's economic failure (Herzfeld 2016), and transformed from 'regular', 'deserving' Europeans into 'irregular' and 'undeserving' Others (Tsoni 2013). Next to the copious mixed flows of 'regular irregulars' of the European constructions of belonging, tens of thousands of 'irregular irregulars' on Lesvos alone - Greece's 'new poor' - are forced to make ends meet as well as they can. However, hardly any of the organizations jostling at the refugee arrival spots or the registration camps on Lesvos ever took any notice of the refugees' real needs (Obordo 2016; TrueLesvos 2016), maintaining, instead, only the shortsighted scope of their often merely photo-opportunistic humanitarian actions.

Eva is a 45-year-old French-language teacher living in the town of Molyvos who is now unemployed and rents out a bedroom of her apartment to rotating volunteers. Her narrative is illustrative of how the entire local society - not just the poorest among them - are caught in the repercussions of the 'refugee crisis' and its aftermath of affective liminality:

Everyone comes here and has one thing in mind: helping the refugees. It's all about the refugee crisis. This is not bad, the whole world is nowadays concerned. But does anyone think about the local people? They were here when all this started, this is their reality for years now and it is only getting worse. The NGOs and the volunteers may come and go as they please. But we have nowhere to go and so we must stay here. What about our crisis? We are not activists. We live here, this is our life but now almost everything is ruined. Not only for the poorer people, but all the rest of us as well. The economy is going from bad to worse and this year tourism has plummeted too. 
The tons of material leftovers changing hands - expendable for some while valuable for others constitutes another metric system, where one person's treasure soon becomes trash which then becomes another's treasure (Tsoni 2016) with the connivance of the local authorities. Deflated rubber dinghies slashed open for anything valuable now lay like gutted sea-mammal carcasses along the shores. Claims over their cheap made-in-China boat engines lead bystanding profiteers to get into bloody fistfights. The equally coveted solid wood boat floorboards are sawn into animal pens, household furniture and balcony separators by local farmers calling dibs on the approaching boats on the horizon. The fluorescent orange grit lining the island's coastline in aerial photographs trying to depict the environmental impact of the 'refugee crisis' is made of fake, non-buoyant lifejackets. Reluctant business start-ups aiming at the sustainable recycling of these materials then popped up under municipal permission, as refugee trash falls within their jurisdictional 'assets'. Small initiatives create tents, hand-made bags, wallets, accessories, and other trinkets to then be sold to cover the needs of refugee reception. After everyone has had their pick, the eventual refuse is gathered in towering mountains at the new 'refugee debris' municipal dump near Molyvos and gets buried every few months. This extensive remediation of waste - both material and human - is approached not merely as a refashioning of something defective or polluted, or as revaluation and realignment back into familiar, everyday political economies of materials discarded within social/ecological environments in which they remain fundamentally 'other'. Remediation also signifies an active reworking of the meanings and affects attached locally to those materials within an eroding social and physical ecology.

Then there are the dead; the hundreds of bodies which those warm azure borders have claimed. Hurriedly buried; unnamed but for a number, a date, and an amateur phenotypical reading to approximate their nationality. Unmourned, unmarked small hills on the far outskirts of the consecrated grounds meant for the proper burial of the entitled. Right by the dumping ground, 'matter out of place' even beyond death's boundaries. Row after row, stumbled upon accidentally in the midst of a forest clearing. Never accounted for, sunk at the bottom of the shallow seaa sea in which amateur divers have stopped spearfishing, for fear of what they, or others, might encounter in their depths; whose fresh fish the colourful wooden tratas unload each day along the jetty, yet some housewives refuse to buy and cook, for fear of what they have fed on. 'There is the [financial] crisis, yes...' a woman around her sixties chuckled at me with a conspiratory smile outside a fishmonger's one morning after surveying what was on sale and getting ready to walk away; '...the crisis has always been the crisis, but we have not turned into cannibals yet!', referring to the fresh sardines' bargain price that morning with a dark 'humor' connotation as to what the fish had eaten in these waters. It is not a rare phenomenon that dead bodies - mostly of children - are washed ashore or caught up in fishermen's nets, several weeks past their unreported drowning.

In the absence of coherent national and European asylum policies, the local refugee reception structures on the island proved unable to cope. Paired with the failure of the national social-welfare policies, the results were catastrophic for a large segment of the local population - both permanent residents and those passing through. New migrants and the receiving communities were left to cope with - and against - each other, under the tremendous pressures for change occurring in the local and extended society. This sudden surge in arrivals caused rapid and massive transformations at multiple levels and between various groups (Rozakou 2015). As social safety-nets were absent, people were called to fend for themselves individually and collectively as well as they could in an unstable context of heightened ambiguity. Meanings, identities, trajectories and prospects remained in constant flux and yet impinged on very specific localities: Lesvos as a whole, together with several key sites of refugee reception such as shores and camps.

The emergent articulations of liminality, expressed through the off- and online narratives of people encountered on the island and then followed backwards and forwards for months or even years, reveals an expanded liminality and broadens its gauge far beyond the previously delimited boundaries within which it was conceptualized and such practises took 
place. Liminality metamorphoses into an extended and mobile condition following those trapped in this 'middle' stage, having the capacity to also encompass all others who participated in this process at different stages and in different capacities and who eventually discover that they have restricted - if any - possibilities of exit.

This observation is my main point of contrast with the classical conceptualization of a ritual passage. According to its definition, it is mandatory to follow a linear progression through the three successive stages. Each step in this passage is integral to its constitution, and reaching the final aggregation and then eventual exit from the ritual is imperative. This linearity has been previously contested as societal and other processes may impede the final transition of liminal persons to reincorporation. However, upon entering the state of liminality in the current refugee context in Lesvos and all over Greece, there is no guarantee of linearity, nor any longer of social upgrade upon completion - no assurance of consummation or even exit. Instead, a debilitating circularity prevails, as failed migrant trajectories loop back within the purgatory of the un/enclosed liminal carceral space (Moran 2013) that the extended south-eastern European borderscape has come to denote: the whole Greek territory, along with its border islands and their camps of subhuman conditions, and even beyond - deep into the recesses of euphemistically prettified 'safe third countries'. Within this situation, any spatial or legal forward movement becomes almost impossible, any sense of time is lost, law becomes some kind of Orwellian 'doublespeak', lives are arrested in deadlock, and passage cements into impasse.

\section{Conclusion: borderscapes as heterotopias of routinized liminality}

Borderscapes (Bocchi et al. 2015) emerge as 'manifold overlapping topologies' around borders resulting from the interplay of discontinuous and fragmented bordering practises between multiple actors. Irregular migrants and refugees who (tres)pass these diffused borders 'trigger' them into activation and deployment of the full range of their different aspects (human, technological, legal etc.), turning landscapes around them into borderscapes: charged fields of dynamic inter-action; juxtaposed non-homogeneous places rife with power relations and hierarchies between relationally positioned actors.

Caught up in the midst of the recent convulsions of the European border and asylum crisis, the socio-spatial identity and political geography of Lesvos are being radically reshaped from a quaint holiday destination, where foreigners and locals alike had the opportunity to enjoy leisurely mobility across the liquid Greek-Turkish borders, into an interstitial transit space, a 'paramilitarized' emergency area, a 'war zone without a war' (Papataxiarchis 2016). The concentration of such diverse assemblages of human, material and symbolic border manifestations in such a limited area turns Lesvos into a complex configuration of space and time in which simultaneous competition and convergence are manifested. Combining landscapes of crisis and deviance, it functions as a dual 'heterotopia', one of those rare 'privileged or sacred or forbidden places, reserved for individuals who are, in relation to society and to the human environment in which they live, in a state of crisis... in which individuals whose behavior is deviant in relation to where the required mean or norm are placed' (Foucault and Miskowiec 1986: 24-25).

The Aegean borderscape is comprised of superimposed heterotopias emerging from the contact of various actors inhabiting, defining or defending the south-eastern European borders, with irregular migrants defying them. Borders and il/legality operating in the everyday life of persons within this landscape create a condition of liminality transcending the spatial confines of these places. Through those actors' on- and offline interactions and the legal and political responses towards them, the spaces which refugees transit or occupy get connected and liminality spills over from the geography 'the closest-in' - the body - to the wider European, Middle Eastern and global sphere.

The borderscape/'refugee-scape' (Papataxiarchis 2016) of Lesvos has become yet another zone of liminal, upredictably permeable un/enclosed carceral space in a series of such spaces - the first upon 
European soil for the irregular newcomers. Located along the fraught political border between Greece and Turkey, Lesvos has been a space of confluence and conflict for generations, a liminal place in the historical geography of the eastern Mediterranean attesting to the vitality and full complexity of and at the border throughout centuries. In this contemporary juncture it reveals the emerging configurations and crises of the existing EU bordering and asylum systems in all their complexity and complicity in the perpetuation of human plight.

Irregular migrants and receiving communities on Lesvos are caught in a protracted and broadened crisis context providing an example of liminality's gradual socio-spatial and temporal 'stretching' into a dominant and portable condition experienced at both the individual and the collective level. Liminality hyperconcentrates into the classic liminal spaces of its two camps on Lesvos and other refugee arrival and reception areas (beaches, roadsides, ports etc.). It simultaneously diffuses, permeating the entirety of the Greek territory where, as of April 2016, approximately 55,000 (officially registered) refugees remain trapped, followed by thousands of itinerant volunteers and activists, mingled with locals in whose backyard this humanitarian tragedy unfolds. The overlapping social, material, spatial and temporal dimensions of their im/mobility collide within the oversignified borderscape in confluence, friction or clash, while people get caught as the ineluctable collateral damage of im/ mobility regimes and bordering practises within this expansive liminal heterotopia.

The routinization of liminality occurs as a process whereby the 'extraordinary' liminal stage, previously vested only in particular people going through particular processes in particular spaces, is gradually stretched spatially and temporally, along with various co-performers of the ritual passage. As extraordinariness is reduced to a routine narrative repeatedly emerging through fieldwork observations, liminality emerges center-stage, not merely as socio-spatial marginality and exclusion but as a prolonged experience of transformation and transition. It is a dynamic process providing a lens through which to examine the perplexing 'time-spaces' and interactions between multiple actors involved in the failing asylum system on Europe's margins: from the monolithic conceptualizations of scale-spanning structures of authority and control, to the agency, resistance and resilience by individuals and collectivities on its receiving end. This protracted sense of liminality may also open up different legal and socio-spatial relations continuously re/produced through the mobility strategies, tactics and practises of various actors who, even while undergoing profound experiences of displacement, alienation and destitution, may maintain and rework a certain sense of being-at-home in the world above and beyond the given untenable conditions of protracted liminality.

\section{Acknowledgments}

With the usual caveats, I am grateful to Giorgos Tyrikos-Ergas for introducing me to the concept of liminality and sharing his longstanding observations on Lesvos with me. I am wholeheartedly thankful to Austin Kocher for his valuable comments throughout the development of this article.

\section{References}

Aldeen, S. (2016) 'The mourning song of the Syrian refugee', Youtube, available at: https://www. youtube.com/watch?v=4-0rGkx1OWI (last accessed 22 April 2016).

Bocchi, G., Laine, J., Brambilla, C. and Scott, J.W., eds (2015) Borderscaping: Imaginations and Practices of Border Making. Farnham: Ashgate.

Foucault, M. and Miskowiec, J. (1986) 'Of other spaces', Diacritics, 16(1): 22-27.

Herzfeld, M. (2016) 'The hypocrisy of European moralism: Greece and the politics of cultural aggression - part 2', Anthropology Today, 32(2): 10-13.

Maravas, E. (2015) 'The Lesvos of poverty: 23,000 fellow citizens asked for municipal social services aid', ERA-Aegean, available at: http://www.era-aegean. $\mathrm{gr} / \mathrm{p}=6129$ (last accessed 22 April 2016). 
Menjívar, C. (2006) 'Liminal legality: Salvadoran and Guatemalan immigrants' lives in the United States', American Journal of Sociology, 111(4): 999-1037.

Moran, D. (2013) 'Carceral geography and the spatialities of prison visiting: visitation, recidivism, and hyperincarceration', Society and Space, 31(1): 174-190.

Obordo, R. (2016) 'Life on Lesbos: residents tell us what it's really like', The Guardian, 16 April.

Papataxiarchis, E. (2016) 'Being "there": at the front line of the "European refugee crisis" - part 1', Anthropology Today, 32(2): 5-9.

Rozakou, K. (2015) 'The passage of Lesvos: crisis, humanitarian governance and solidarity', Synchrona Themata, 130-131: 13-16.

Stoetzer, B. (2014) 'A path through the woods: remediating affective landscapes in documentary asylum worlds', Transit, 9(2).

TrueLesvos (2016) 'The reality of the refugee crisis in Lesvos, Greece', Medium.com. Available at: https:// medium.com/@TrueLesvos/the-reality-of-the-refugeecrisis-in-lesvos-greece-b4af46240888\#.8bwn54akl (last accessed 22 April 2016).
Tsoni, I. (2013) 'African border-crossings in a "city of Others": constellations of irregular im/mobility and in/equality in the everyday urban environment of Athens', Journal of Mediterranean Studies, 27(1): 141-169.

Tsoni, I. (2016) 'Trash/traces: lives adrift along the border', Youtube. Available at: https://www.youtube. $\mathrm{com} /$ watch?v=6ODKuyE-x $1 \mathrm{w}$ (last accessed 22 April 2016).

Turner, V.W. (1967) The Ritual Process: Structure and Anti-Structure. Harmondsworth: Penguin.

Turner, V.W. (1979) Process, Performance, and Pilgrimage: A Study in Comparative Symbology, Vol. 1. New Delhi: Concept Publishing.

UNHCR (2015) 'Greece: Lesvos island snapshot', ReliefWeb, 31 December 2015. Available at: http:// reliefweb.int/sites/reliefweb.int/files/resources/ Daily_Arrival_Greece_31122015.pdf (last accessed 22 April 2016).

UNHCR (2016) 'Greece - sea arrivals 2015', available at: http://data.unhcr.org/mediterranean/ download.php?id=442 (last accessed 22 April 2016).

Van Gennep, A. (1960) The Rites of Passage. Chicago, IL: Chicago University Press. 